\title{
The use of a 2-aminoethylphosphonate by the mesophilic Penicillium commune strain
}

\author{
NATALIA StosieK *, MagdalENA KLIMEK-OCHAB \\ Wrocław University of Science and Technology, Wrocław, Poland
}

\begin{abstract}
The recognition of the breakdown mechanisms of naturally occurring phosphonates is very important to understand the distribution mechanisms of their synthetic derivatives that are deposited in large amounts in the environment - for example, $N$-phosphonomethylglycine (PMG; glyphosate), the main component of the popular herbicide Roundup, increasingly perceived as having a negative impact on people and the environment. The mesophilic fungal strain Penicillium commune is capable of splitting the phosphorus-carbon bond in 2-aminoethylphosphonic acid (2-AEP; ciliatine). Growing the fungi on a modified chemically defined medium containing $2 \mathrm{mM}$ 2-AEP as the only P source for growth resulted in a $50 \%$ loss of the substrate in the culture medium, as confirmed by the high-performance liquid chromatography analysis. The activity of enzymes that metabolize ciliatine was detectable in a cell-free extract prepared from Penicillium commune pre-grown on $2 \mathrm{mM}$ 2-AEP. The activity of the crude extract was demonstrated at $30^{\circ} \mathrm{C}$.
\end{abstract}

Key word: 2-aminoethylphosphonate (2-AEP; ciliatine), biodegradation, organophosphonates, phosphorus-carbon bond cleavage, mesophilic strain, Penicillium commune

\section{Introduction}

In many living organisms, ranging from microorganisms to mammalian tissues, 2-aminoethylphosphonic acid (2-AEP; ciliatine) is the most common, naturally occurring, and ubiquitous phosphonate (Horiguchi and Kandatsu, 1959; Cembella an Antia, 1986; Blackburn, 1981). Ciliatine is characterized by the presence of a stable carbon-phosphorus (C-P) bond, which makes it resistant to chemical hydrolysis and thermal decomposition (Kononowa and Nesmeyanowa, 2002). In addition, this compound is a relevant precursor for the biosynthesis of phosphonoglycans, phosphonolipids, and phosphonoproteins (Baumann et al., 1992; Kariotoglou and Mastronicolis, 2001). Due to the occurrence of ciliatine in the natural environment, microorganisms have evolved a unique degradation pathway to convert 2-AEP into a source of nutrients for growth (Klimek-Ochab et al., 2007). 2-AEP is rapidly degraded by most bacteria (Cook et al., 1978; Dumora et al., 1983; Ternan and Quinn,
1998; Kononova and Nesmeyanowa, 2002). The transport of 2-AEP molecule into the bacterial cell is induced by its very presence and is specific for phosphonates. The $\mathrm{C}-\mathrm{P}$ bond cleavage in a ciliatine molecule takes place in the absence of inorganic phosphate $(\mathrm{Pi})$ in the environment. Biodegradation of the 2-AEP molecule is a two-step process. The first step consists of substrate transamination catalyzed by 2-AEP transaminase; as a result, phosphonoacetaldehyde and a corresponding amino acid are formed (Kim et al., 2002). 2-AEP transaminase [EC 2.6.1.37] was isolated from Pseudomonas aeruginosa (Dumora et al., 1983; Dumora et al., 1989) and Salmonella typhimurium (Kim et al., 2002); however, it occurs in other microorganisms as well (e.g. Bacillus cereus (La Nauze and Rosenberg, 1968) or Pseudomonas putida NG2 (Ternan and Quinn, 1998)). Substrate transamination occurs in the presence of pyridoxal phosphate that acts as a cofactor specific for pyruvate (the acceptor of amino group), whereas 2-AEP is an amino group

\footnotetext{
* Corresponding author: Wrocław University of Science and Technology, Wybrzeże Wyspiańskiego 29, 50-370 Wrocław, Poland; e-mail: natalia.stosiek@pwr.edu.pl
} 
donor (Chen et al., 2002). In the next step, phosphonoacetaldehyde hydrolase (phosphonatase) [EC 3.11.1.1] catalyzes the hydrolysis of phosphonoacetaldehyde to form acetaldehyde and Pi (Allen and Dunaway-Mariano, 2004). This enzyme was isolated and purified from bacterial strains: Bacillus cereus, Pseudomonas aeruginosa, and Enterobacter aerogenes (La Nauze et al., 1970; Dumora and Lacoste, 1989, Lee et al., 1992).

Studies on the biodegradation of naturally occurring phosphonates are increasingly becoming popular because the recognition of the mechanisms of its decomposition forms the basis for understanding the mechanisms of distribution of synthetic derivatives of these compounds that are deposited in huge amounts in the environment. In recent years, the use of anthropogenic phosphonates has grown very rapidly, especially in agriculture. Glyphosate (N-phosphonomethyl-glycine; $\mathrm{PMG}$ ) is the most widely used synthetic phosphonate in the world. As a non-selective organophosphorus pesticide with a very broad spectrum of activity, it is particularly useful in agriculture, where it is known under the tradename Roundup ${ }^{\circledR}$ (Mañas et al., 2009). The presence of glyphosate has been detected not only in soil, but also in aquatic environments (Skeff et al., 2015). Knowledge of the mechanisms of decomposition of phosphonic compounds is the basis of biotechnological methods of environmental protection, as these compounds enter the environment in an uncontrolled manner.

Furthermore, 2-AEP occurs in combination with glycans, lipids, and proteins in some pathogenic organisms (Trypanosoma cruzi, Tetrahymena pyriformis, etc.) (Colli and Manso Alves, 1999; Vinogradov et al., 2001; Sarkar et al., 2003) or harmful insects (Locusta migratoria) (Hard et al., 1993), which is necessary in the process of host-cell infection and survival in its body. Detailed information on enzymes involved in 2-AEP utilization should help to rationally design and synthesize appropriate inhibitors that will allow control of the growth and multiplication of 2-AEP-dependent pathogens.

The biodegradation of ciliatine was studied mainly in bacteria, and the mechanism of the reaction in many prokaryotic strains is well known. However, many doubts about the utilization of this compound in eukaryotic strains remain. The more that is known about the participation of individual groups of soil microorganisms and their ability to decompose organophosphorus compounds, the closer to reality will become the picture of what is happening in the environment. In this paper, we demonstrate the biodegradation of ciliatine by a mesophilic strain Penicillium commune that was carried out at $27^{\circ} \mathrm{C}$. This naturally occurring compound is metabolized for cell purposes, and an activity of the cell-free extract toward 2-AEP was detected.

\section{Materials and methods}

\section{Chemicals}

All chemicals and reagents were of the highest available purity; gradient high-performance liquid chromatography (HPLC) solvents and phosphonate (2-AEP) were purchased from Merck (Poznan, Poland) unless otherwise stated. DEAE-Sephacel was purchased from Amersham Biosciences. Culture media components were obtained from Avantor (Gliwice, Poland).

\section{Microorganism}

The mesophilic fungal strain $P$. commune was a generous gift from Prof. A. M. Picco from the collection of the Mycology Institute of Pavia, Italy. The microorganism was identified by Prof. Wacław Dąbrowski, from the Institute of Agricultural and Food Biotechnology (Warsaw), by sequencing the rDNA ITS1-ITS4 fragment (data not shown). Accordingly, the strain was identified as $P$. commune (IAFB 2513).

The fungus was maintained routinely on Czapek Dox Medium (CDM) agar, which allowed for the necessary sporulation required for inoculum collection.

\section{Growth conditions}

P. commune was grown on modified liquid $\mathrm{CDM}(\mathrm{pH}$ 7-7.2) that contained, per liter: $30 \mathrm{~g}$ glucose, $0.5 \mathrm{~g}$ $\mathrm{MgSO}_{4} \cdot 7 \mathrm{H}_{2} \mathrm{O}, 0.5 \mathrm{~g} \mathrm{KCl}, 10 \mathrm{mg} \mathrm{FeSO}{ }_{4} \cdot 7 \mathrm{H}_{2} \mathrm{O}, 3 \mathrm{~g}$ $\mathrm{NaNO}_{3}$, and $1 \mathrm{~g} \mathrm{~K}_{2} \mathrm{HPO}_{4}$. On the basis of experimental assumptions, the phosphorus source was omitted and replaced with filter-sterilized $2 \mathrm{mM}$ 2-AEP (as the sole phosphorus source) similar to that used in the standard CDM. Liquid cultures $(50 \mathrm{ml}$ in 250-ml Erlenmeyer flasks) were inoculated with a fungal spore suspension in $0.05 \%$ Triton $\mathrm{X}-100$ and incubated at $27^{\circ} \mathrm{C}$ on a rotary shaker at $140 \mathrm{rpm}$. Cultures were maintained for 9 days, and samples of $1 \mathrm{ml}$ were taken each day to monitor the concentration of the substrate (2-AEP) by HPLC whereas product $(\mathrm{Pi})$ concentration was monitored by the colorimetric method (Malachite Green Phosphate Assay) 
in the post-culture fluid. Simultaneously, control experiments were carried out on a mineral medium containing $\mathrm{K}_{2} \mathrm{HPO}_{4}(2 \mathrm{mM})$. The standard curve was prepared using $\mathrm{K}_{2} \mathrm{HPO}_{4}$ dissolved in the medium. Glucose did not interfere with the Pi measurement in tested samples (data not shown). Mycelium from control and experimental samples was harvested by vacuum filtration onto filter paper (Rotilabo ${ }^{\circledR}$-round filters, cellulose, membrane $240 \mathrm{~mm}$, Roth) and its growth was evaluated by dry mass determination. Filters with fungal biomass were dried for 48 hours in an oven at $70^{\circ} \mathrm{C}$ and then weighed.

\section{Growth conditions under nutrient-deficient state}

$P$. commune was first cultivated until the early midlog phase on a modified liquid CDM containing $\mathrm{K}_{2} \mathrm{HPO}_{4}$ as the sole $\mathrm{P}$ source. In order to introduce a nutrient-deficient state, the biomass was harvested by centrifugation $\left(4000 \mathrm{rpm}, 10 \mathrm{~min}\right.$ ) after incubation at $27^{\circ} \mathrm{C}$ on a rotary shaker $(140 \mathrm{rpm})$ for 3 days, washed twice with distilled water, and then transferred to Erlenmeyer flasks $(250 \mathrm{ml})$ containing $100 \mathrm{ml}$ distilled water. After 24-hour starvation, the biomass was transferred to the liquid $\mathrm{CDM}$ containing $2 \mathrm{mM}$ 2-AEP as the sole $\mathrm{P}$ source. The cultures were incubated on a rotary shaker (140 rpm) at $27^{\circ} \mathrm{C}$ for 9 days.

\section{Analytical methods}

\section{Malachite Green Phosphate Assay}

The Pi concentration was determined by the colorimetric method of the Malachite Green Phosphate Assay (Lanzetta et al., 1979). The method enables measurement of the amount of the free $\mathrm{Pi}$ in aqueous solutions. A calorimetric analysis allows the detection of nanomolar $\mathrm{Pi}$ concentrations in the sample. Potassium monophosphate was used as a reference to create a standard curve, which was repeated for each freshly prepared stock of the reagent mixture.

\section{Bradford protein assay}

The protein content was assayed by the Bradford method (1976) using bovine serum albumin (Merck) as the standard reference.

\section{HPLC analysis (Kawai et al., 1991)}

We used HPLC to determine the change in 2-AEP concentrations in the culture medium. The sample containing 2-aminophosphonic acid was centrifuged for $5 \mathrm{~min}$ at $1300 \mathrm{rpm}$. Then, $1 \mathrm{ml}$ was aliquoted from the sample and $0.5 \mathrm{ml}$ of $0.4 \mathrm{mM}$ phosphate buffer was added $\left(\mathrm{Na}_{2} \mathrm{HPO}_{4} / \mathrm{Na}_{3} \mathrm{PO}_{4}, \mathrm{pH} 11\right)$. Subsequently, $0.2 \mathrm{ml}$ of $p$-toluenosulfonyl chloride $(10 \mathrm{mg} / \mathrm{ml}$ acetonitrile $)$ was added to the mixture and incubated in $50^{\circ} \mathrm{C}$ for $5 \mathrm{~min}$. Subsequently, $10 \mu \mathrm{l}$ of the reaction mixture was injected onto the HPLC column according to the principles governing the use of the apparatus. The mobile phase comprised $0.2 \mathrm{M}$ phosphate buffer $\left(\mathrm{H}_{3} \mathrm{PO}_{4} / \mathrm{NaH}_{2} \mathrm{PO}_{4}\right)$ and acetonitrile mixed in $85: 15$ ratio. The analyses were carried out at $50^{\circ} \mathrm{C}$ at a flow rate of $1 \mathrm{ml} / \mathrm{min}$. The tosylation of aminophosphonate was detected at a wavelength of $240 \mathrm{~nm}$.

Each series of analyzes was preceded by an injection into the column of standard samples for which the concentration of the aminophosphonic compound was known. The concentration of the test compound in the analyzed sample was calculated on the basis of the peak area as compared to the standard sample. Each analysis was conducted in triplicate.

\section{Preparation of cell-free extract}

Fungal cultures were grown on a modified liquid $\mathrm{CDM}$ containing 2-AEP as the sole phosphorus source, on a rotary shaker $(140 \mathrm{rpm})$ at $27^{\circ} \mathrm{C}$ for 5 days until they reached the early mid-log phase. Thereafter, the microbial biomass was harvested by centrifugation $(4000$ $\mathrm{rpm}, 15 \mathrm{~min}$ ) and washed thrice with ice-cold $50 \mathrm{mM}$ Tris- $\mathrm{HCl}$ buffer ( $\mathrm{pH}$ 7.5), and disrupted ultrasonically using a Cole Parmer Torbeo 36800 600-W sonicator-four cycles of 30 -second sonication and cooling for $2 \mathrm{~min}$; the amount of secreted protein was monitored each time by the Bradford method (1976). Cell debris was removed by double centrifugation; the first was carried out at $3500 \mathrm{rpm}$ for $10 \mathrm{~min}$, and the supernatants were transferred to Eppendorf tubes and centrifuged at $14000 \mathrm{rpm}$ for $10 \mathrm{~min}$. The cell-free extracts obtained were desalted overnight by dialysis in Tris- $\mathrm{HCl}$ buffer ( $\mathrm{pH} 7.5$ ) in $4^{\circ} \mathrm{C}$. Then, the desalted cell-free extract was loaded onto the DEAE-Sephacel column equilibrated with the same buffer as in the dialysis and subjected to pre-purification using the Tris- $\mathrm{HCl}$ buffer ( $\mathrm{pH}$ 7.5). Fractions containing the highest amounts of protein were combined and used to determine the activity of the cell-free extract. The above steps of extract preparation, starting from the dialysis, were undertaken at $10^{\circ} \mathrm{C}$ unless otherwise stated (Klimek-Ochab et al., 2003). 


\section{Assays of the activity of cell-free extract}

The $\mathrm{C}-\mathrm{P}$ bond disruption in a cell-free extract obtained from $P$. commune by utilizing the naturally occurring phosphonate was tested in a coupled transamination-dephosphonylation reaction by using the modified method of Cook and coworkers (1978). The reaction mixture $(100 \mu \mathrm{l})$ contained $50 \mathrm{mM}$ Tris- $\mathrm{HCl}$ buffer (pH 8), $5 \mathrm{mM} \mathrm{MgCl}_{2}$, $1 \mathrm{mM}$ pyridoxal-5-phosphate, $0.5 \mathrm{mM}$ DTT, $0.5 \mathrm{mM}$ EDTA, and $5 \mathrm{mM}$ 2-AEP. Because it was not known which molecules could be an acceptor of the amino group ( $\alpha$-ketoglutaric acid, sodium pyruvate, oxalacetic acid), a combination of three possible acceptors was introduced into the reaction mixture at a concentration of $10 \mathrm{mM}$ each. The reaction was carried out at $30^{\circ} \mathrm{C}$. After the appropriate incubation time (up to $60 \mathrm{~min}$ ), the amount of Pi released was quantified calorimetrically by using the Malachite Green Phosphate Assay. Additionally, blanks were carried out without either 2-AEP or a cellfree extract. The crude extract activity toward 2-AEP was expressed as the amount of phosphate released per second per milligram of protein $\left(\mathrm{s}^{-1} \mathrm{mg}\right.$ protein $\left.{ }^{-1}\right)$. Each analysis was conducted in triplicate.

\section{Results and discussion}

The study of the degradative ability of natural phosphonate-ciliatine has been the subject of intensive research for many years. This process has been thoroughly studied in bacteria and, in recent years, increasing attention has been paid to eukaryotic organisms, mainly fungi, which constitute approximately $50 \%$ of the soil biomass (Zboińska et al., 1992; Klimek-Ochab et al., 2007; Klimek-Ochab, 2008). Fungi have enormous enzymatic potential that allows them to use a range of natural and synthetic compounds for cell processes (Weiland et al., 1995; Bending et al., 2002). On the other hand, the synthesis of organophosphorus compounds from the group of phosphonates in fungi is quite rare. Therefore, the contribution to the biodegradation of a stable $\mathrm{C}-\mathrm{P}$ bond in phosphonate molecules makes this group of soil microflora representatives very interesting.

In this work, we described the ability of $P$. commune strains to utilize 2-AEP as the sole phosphorus source. To determine the basic phosphorus requirement for the growth of $P$. commune, it was cultivated on a modified $\mathrm{CDM}$ containing $2 \mathrm{mM} \mathrm{Pi}$ as the sole $\mathrm{P}$ source. The results are shown in Figure 1.

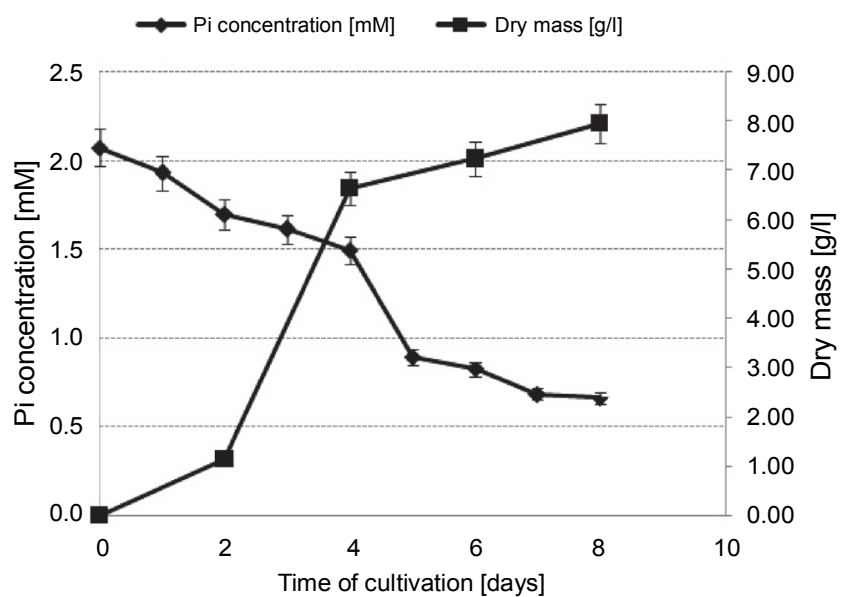

Fig. 1. The growth of Penicillium commune and substrate utilization during cultivation on a medium containing $2 \mathrm{mM} \mathrm{Pi}$ as the only $\mathrm{P}$ source; data are means $\pm \mathrm{SD}$ of three replications

As shown in Figure 1, the greatest consumption of $\mathrm{Pi}$ from the cultivation medium (from 1.70 to $0.9 \mathrm{mM}$ ) took place between the second and fifth day of cultivation during the most intense growth of the fungal biomass.

In the next step to accurately examine the growth of $P$. commune on a phosphorus source, the $\mathrm{Pi}$ in the cultivation medium was changed to $2 \mathrm{mM} 2 \mathrm{AEP}$ as the sole $P$ source, for a careful study of the growth of the mesophilic strain. The results obtained are shown in Figure 2.

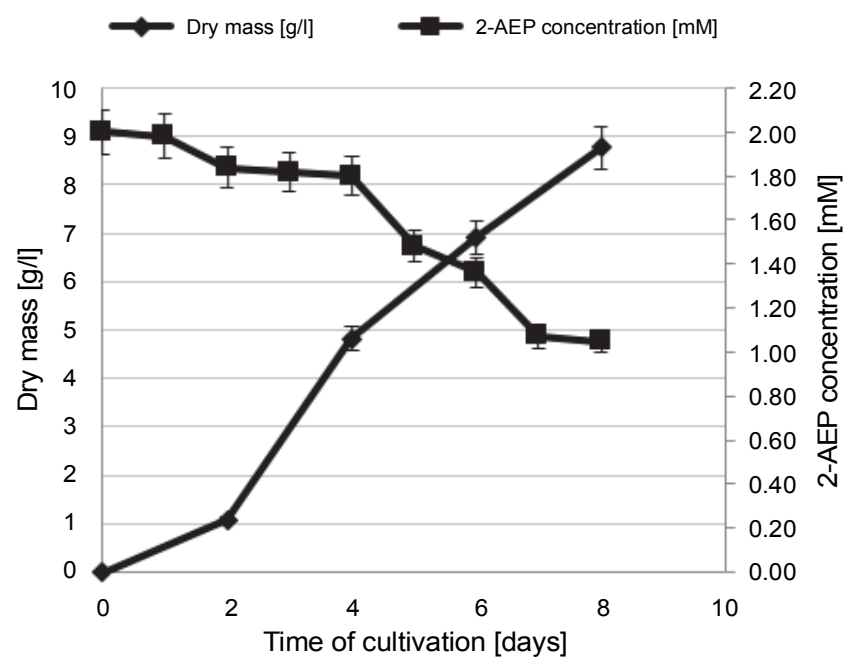

Fig. 2. The growth of Penicillium commune and change in 2-AEP concentration during cultivation on a medium containing $2 \mathrm{mM}$ 2-AEP as the only $\mathrm{P}$ source; data are means $\pm \mathrm{SD}$ of three replications

When $2 \mathrm{mM}$ 2-AEP was added to the medium as the only phosphorus source, the fungal strain used up to 
Table 1. The amount of biomass as well as 2-AEP and Pi concentrations in cultivation medium by Penicillium commune after 9 days of cultivation; data are means \pm SD over three replications

\begin{tabular}{l|c|c|c}
\hline $\begin{array}{c}\text { Source of phosphorus } \\
\text { in a modified CDM }\end{array}$ & $\begin{array}{c}\text { Biomass yield } \\
{[\mathrm{g} / \mathrm{l}]}\end{array}$ & $\begin{array}{c}\text { Final }^{1} \text { 2-AEP concentration } \\
{[\mathrm{mM}]}\end{array}$ & $\begin{array}{c}\text { Pi concentration } \\
{[\mathrm{mM}]}\end{array}$ \\
\hline $2 \mathrm{mM} \mathrm{Pi}$ & $7.933 \pm 0.012$ & $\mathrm{n} / \mathrm{a}$ & $0.493 \pm 0.005$ \\
\hline $2 \mathrm{mM} 2-\mathrm{AEP}$ & $8.767 \pm 0.036$ & $1.044 \pm 0.003$ & $0.077 \pm 0.001$ \\
\hline $5 \mathrm{mM} 2-\mathrm{AEP}$ & $9.860 \pm 0.017$ & $1.512 \pm 0.001$ & $0.021 \pm 0.002$ \\
\hline $2 \mathrm{mM} 2-\mathrm{AEP}+2 \mathrm{mM} \mathrm{Pi}$ & $9.140 \pm 0.035$ & $1.937 \pm 0.001$ & $0.054 \pm 0.001$ \\
\hline $2 \mathrm{mM} 2-\mathrm{AEP}+0.2 \mathrm{mM} \mathrm{Pi}$ & $8.949 \pm 0.017$ & $1.305 \pm 0.003$ & $0.020 \pm 0.003$ \\
\hline
\end{tabular}

${ }^{1}$ Final concentration of 2-AEP in the medium after 9 days of cultivation

$50 \%$ of the substrate. The biodegradation process was accompanied by the release of $\mathrm{Pi}$ into the cultivation medium (data not shown), yielding a final concentration of $0.077 \pm 0.001 \mathrm{mM}$ after 8 days of cultivation.

The growth of the fungal strain on a medium containing 2-AEP or Pi as a sole phosphorus source was compared. The results obtained were comparable, both in terms of the duration of individual growth phases (data not shown) and the quantity of the biomass produced (2 mM Pi $7.933 \pm 0.012 \mathrm{~g} ; 2 \mathrm{mM}$ 2-AEP $8.767 \pm 0.036 \mathrm{~g}$ ).

Furthermore, it was interesting to check whether the strain degrades ciliatine in the presence of other, more easily absorbable, phosphorus sources and how a higher concentration of phosphonate in the medium influences growth and substrate utilization. To further characterize the distribution of ciliatine by $P$. commune during cultivation on a modified CDM simultaneously containing various concentrations of 2-AEP as well as of both substrates (2-AEP and $\mathrm{Pi}$ ) as the sole $\mathrm{P}$ source for growth, the concentration of the Pi released and the utilization of 2-AEP in time were investigated. Simultaneously, control experiments were carried out on a mineral medium containing $\mathrm{K}_{2} \mathrm{HPO}_{4}$ instead of 2-AEP and un-inoculated CDM supplemented with 2-AEP (data not shown). All experiments were conducted at least in triplicate. The results obtained are shown in Table 1 .

As shown in Table 1, the amount of biomass produced was comparable regardless of the source of phosphorus used in the medium. The rate of 2-AEP utilization as well as the amount of Pi released into the medium differed between individual cultures. The addition of $2 \mathrm{mM}$ ciliatine into the CDM resulted in 50\% use of the compound after 9 days of cultivation. Interestingly, a higher concentration of 2-AEP $(5 \mathrm{mM})$ resulted in a lower usage of the substrate $(<25 \%)$. However, if both substrates 2-AEP and the Pi - were used simultaneously in the medium, the phosphonate concentration changed slightly. This is confirmed by data in the literature which report that fungi use $\mathrm{Pi}$ for cell processes when it is present in the medium as the sole P source (Klimek-Ochab et al., 2003). The level of phosphonic substrate utilization and the amount of Pi released during cultivation on a modified CDM containing 2-AEP and $\mathrm{Pi}$ as the sole $\mathrm{P}$ source are shown in Figure 3 and Figure 4.

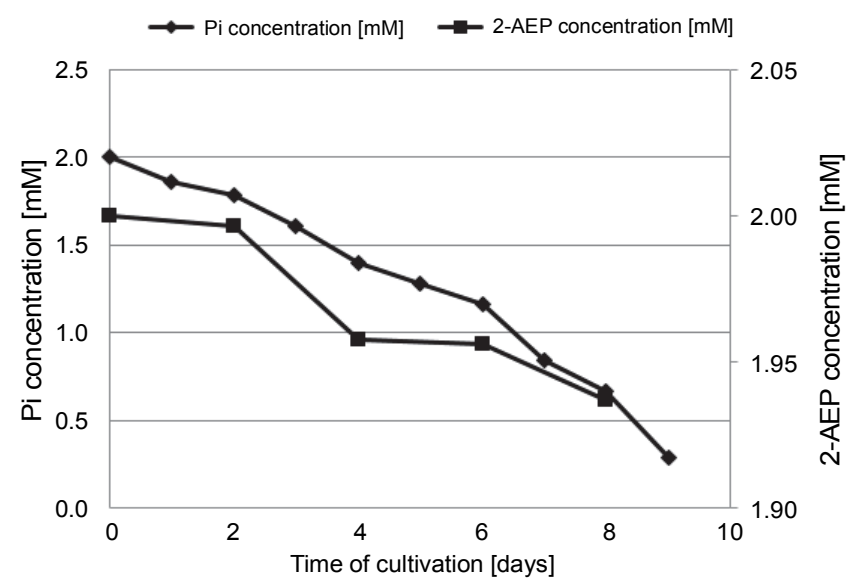

Fig. 3. Changes in the 2-AEP concentration and the level of phosphate liberated into the medium during cultivation on $2 \mathrm{mM}$ 2-AEP and $2 \mathrm{mM}$ inorganic phosphate used as a $\mathrm{P}$ source

When the amount of inorganic phosphate in the medium was insufficient for the fungal subsistence $(0.2 \mathrm{mM})$, and after it had been used up, the 2-AEP was utilized. The final value of 2-AEP in the medium after 9 days of cultivation was $1.305 \mathrm{mM}$. However, when $2 \mathrm{mM}$ $\mathrm{Pi}$ was present in the cultivation medium containing $2 \mathrm{mM}$ ciliatine, the concentration of phosphonate in the 


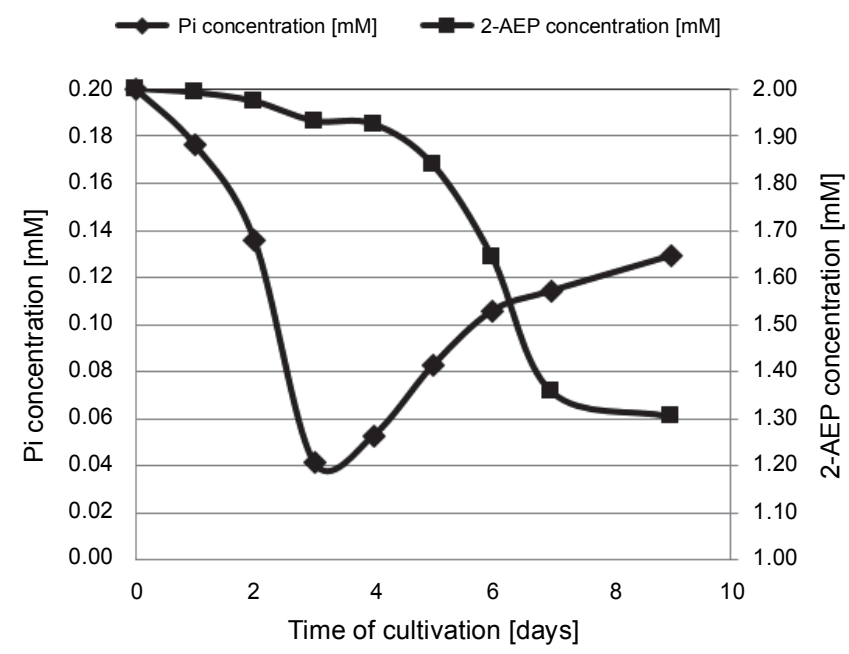

Fig. 4. Changes in the 2-AEP concentration and the level of phosphateliberated into the medium during cultivation on $2 \mathrm{mM}$ 2-AEP and $0.2 \mathrm{mM}$ inorganic phosphate used as a $\mathrm{P}$ source

medium decreased insignificantly to $1.937 \mathrm{mM}(<4 \%)$. These data clearly show that the phosphonic substrate is used only after the Pi has been exhausted in the culture medium, which confirms that the degradation of the phosphonate occurs in a phosphate-dependent manner.

In order to increase the efficiency of the biodegradation process, the fungal strain was also cultured under stress conditions to cause nutrient deficiency. The results are shown in Figure 5.

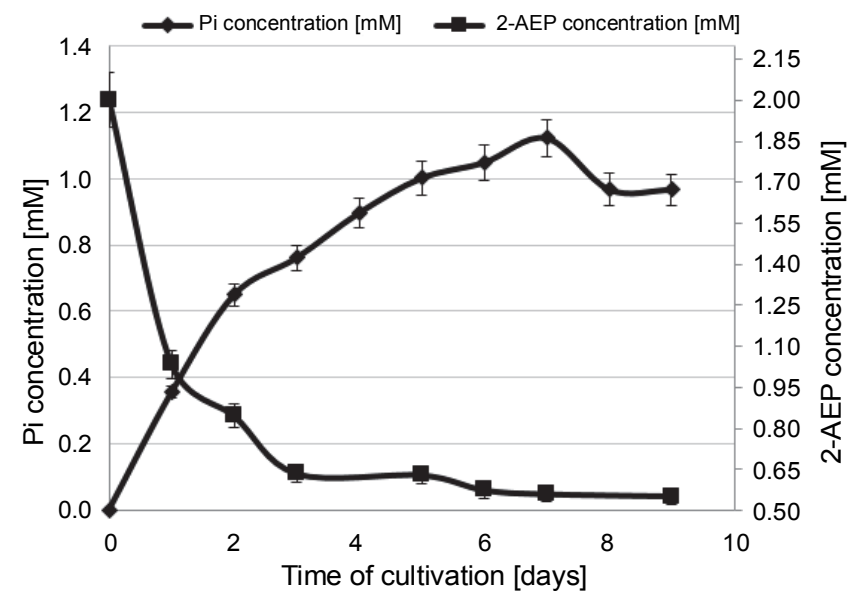

Fig. 5. Changes in the 2-AEP concentration and the amounts of phosphate liberated into the medium during cultivation on $2 \mathrm{mM}$ 2-AEP after the deficiency of nutrients was introduced; data are means \pm SD over three replications

The introduction of a fungus to a nutrient-deficient state stimulated the production of a biomass in a slightly higher amount as compared to previous experiments
$(9.518 \pm 0.041 \mathrm{~g} / \mathrm{l})$ and a very high utilization of the 2-AEP substrate, which reached over $70 \%$. However such a cultivation procedure significantly extends the time of the process (by 6 days as compared to the cultivation carried out without inducing the nutrient-deficient state) and causes accumulation of large amounts of $\mathrm{Pi}$ in the cell, which later makes it difficult to determine the activity of the cell-free extract (data not shown).

Furthermore, the studies confirmed the presence of enzymes involved in the breakdown of the $\mathrm{C}-\mathrm{P}$ bond of 2-AEP in the cell-free extract of $P$. commune. The ultrasonic method for cell disruption allowed us to obtain a crude extract containing $205 \mu \mathrm{g} / \mathrm{ml}$ of the released protein. The crude extract prepared from $P$. commune pregrown on $2 \mathrm{mM}$ 2-AEP as the sole $\mathrm{P}$ source had detectable 2-AEP transaminase and phosphonoacetaldehyde hydrolase (phosphonatase) activities toward the ciliatine molecule when assayed at $30^{\circ} \mathrm{C}$. A specific activity of $3.39 \pm 0.04 \mathrm{nmol}$ of $\mathrm{Pi}$ that was released per second per milligram of protein was detected. The storage of crude cell extract for 24 hours at $4{ }^{\circ} \mathrm{C}$ resulted in a slight change in its activity ( $8 \%$ decrease), which indicates that the enzymes involved in the ciliatine degradation remain relatively stable and are not sensitive to low temperatures (Klimek-Ochab et al., 2014).

The enzymatic activity of a crude extract is comparable to that previously obtained for Penicillium strains (Klimek-Ochab, et al., 2007). This genus is characterized by much higher values of cell-free extract activities as compared to bacterial strains, as was demonstrated (e.g. for phosphonoacetate hydrolase) (Klimek-Ochab, et al. 2003). Previous studies on $P$. commune (Klimek-Ochab et al., 2007) indicate that, in fungi, the enzymes involved in the 2-AEP degradation process are the same as in bacteria (2-AEP transaminase and phosphonatase); however, they differ from the enzymes of prokaryotic origin that are described in the literature, for example, from Escherichia coli (Wanner, 1996). Among others, the fungal transaminase is characterized by a higher substrate specificity and can tolerate various amino group donors - that is, $\alpha$-ketoglutaric acid, sodium pyruvate, and oxalacetic acid (Klimek-Ochab et al., 2007). A detailed research work is currently being conducted on the enzymes involved in the 2-AEP mineralization from the $P$. commune strain in order to obtain detailed information on the properties and regulatory mechanisms of the proteins involved in this process. 


\section{Conclusions}

Detailed knowledge about the mechanisms of degradation of naturally occurring phosphonates and their derivatives undoubtedly has an ecological dimension and allows a better understanding of the molecular basis of phosphonic xenobiotics distribution in the environment. It is important to know the fate of synthetic phosphonates because the use of these compounds has been growing in recent years, but there are no data on phosphonate concentrations in the environment. The dynamics of phosphonate biotransformation in the natural environment still remains unexplored because, in its description, we cannot omit one of the most numerous groups of microorganisms with enormous enzymatic potential - the fungi.

\section{Acknowledgments}

The work was financially supported by a statutory activity subsidy from the Polish Ministry of Science and Higher Education for the Faculty of Chemistry of Wrocław University of Science and Technology.

\section{References}

Allen K.N., Dunaway-Mariano D. (2004) Phosphoryl group transfer: evolution of a catalytic scaffold. Trends Bioch. Sci. 29(9): 495-503.

Baumann H., Tzianabos A.O., Brisson J.R., Kasper D.L., Jennings H.J. (1992) Structural elucidation of two capsular polysaccharides from one strain of Bacteroides fragilis using high-resolution NMR spectroscopy. Biochemistry 31(16): 4081-4089.

Bending G.D., Friloux M., Walker A. (2002) Degradation of contrasting pesticides by white rot fungi and its relationship with ligninolytic potential. FEMS Microbiol. Lett. 212: 59-63.

Bradford M.M. (1976) A rapid and sensitive method of the quantitation of microgram quantities of protein utilizing the principle of protein-dye binding. Anal Biochem. 72: 248-254.

Blackburn G.M. (1981) Phosphonates as analogues of biological phosphonates. J. Chem. Ind. 7: 134-138.

Cembella A.D., Antia N.J. (1986) The determination of phosphonates in seawater by fractionation of the total phosphorus. Marine Chem. 19(3): 205-210.

Chen C.C., Zhang H., Kim A.D., Howard A., Sheldrick G.M., Mariano-Dunaway D., Herzberg O. (2002) Degradation pathway of the phosphonate ciliatine: crystal structure of 2-aminoethylphosphonate transaminase. Biochemistry 41(44): 13162-13169.

Cook A.M., Daughton C.G., Alexander M. (1978) Phosphonate utilization by bacteria. J. Bacteriol. 133: 85-90.

Dumora C., Lacoste A.M., Cassaigne A. (1983) Purification and properties of 2-aminoethylphosphinate: pyruvate aminotransferase from Pseudomonas aeruginosa. Eur. J. Biochem. 133: 119-125.

Dumora C., Lacoste A.M., Cassaigne A. (1989) Phosphonoacetaldehyde hydrolase from Pseudomonas aeruginosa, purification, properties and comparison with Bacillus cereus enzyme. Bioch. Biophys. Acta 997: 193-198.

Hard K., Van Doorn J.M., Thomas-Oates J.E., Kamerling J.P., Van der Horst D.J. (1993) Structure of the asn-linked oligosaccharides of apolipophorin III from the insect Locusta migratoria. Carbohydrate-linked 2-aminoethylphosphonate as a constituent of a glycoprotein. Biochemistry 32: 766-775.

Horiguchi M., Kandatstu M. (1959) Isolation of 2-aminoethane phosphonic acid from rumen protozoa. Nature 184(4690): 901.

Kariotoglou D.M., Mastronicolis S.K. (2001) Sphingophosphonolipids, phospholipids, and fatty acids from Aegean jellyfish Aurelia aurita. Lipids 36(11): 1255.

Kawai S., Uno B., Tomita M. (1991) Determination of glyphosate and its major metabolite aminomethylphosphonic acid by high-performance liquid chromatography after derivatization with p-toluenesulphonyl chloride. J. Chromatogr. A 540: 411-415.

Kim A.D., Baker A.S., Dunaway-Mariano D., Metcalf W.W., Wanner B.L., Martin B.M. (2002) The 2-aminoethylphosphonate-specific transaminase of the 2-aminoethylphosphonate degradation pathway. J. Bacteriol. 184: 4134-4140.

Kononova S.V., Nesmeyanowa M.A. (2002) Phosphonates and their degradation by microorganisms. Biochemistry (Mosc). 67: 184-195.

Klimek-Ochab M., Lejczak B., Forlani G. (2003) A metal-independent hydrolase from a Penicillium oxalicum strain able to use phosphonoacetic acid as the only phosphorus source. FEMS Microbiol. Lett. 222(2): 205-209.

Klimek-Ochab M., Obojska A., Picco A.M., Lejczak B. (2007) Isolation and characterization of two new microbial strains capable of degradation of the naturally occurring organophosphonate-ciliatine. Biodegradation 18: 223-231.

Klimek-Ochab M. (2008) Degradation of phosphonates by fungi. Curr. Trends Microbiol. 4: 91.

Klimek-Ochab M., Mucha A., Żymańczyk-Duda E. (2014) 2-Aminoethylphosphonate utilization by the cold-adapted Geomyces pannorum P11 strain. Curr. Microbiol. 68(3): 330-335.

La Nauze J.M., Rosenberg H. (1968) The identification of 2-phosphonoacetaldehyde as an intermediate in the degradation of 2-aminoethylphosphonate by Bacillus cereus. Biochim. Biophys. Acta 165(3): 438-447.

La Nauze J.M., Rosenberg H., Shaw D.C. (1970) The enzymatic cleavage of the carbon-phosphorus bond:purification and properties of phosphonatase. Biochim. Biophys. Acta 212: 332-350.

Lanzetta P.A., Alvarez L.J., Reinach P.S., Candia O.A. (1979) An improved assay for nanomole amounts of inorganic phosphate. Anal. Biochem. 100: 95-97.

Lee K.S., Metcalf W.W., Wanner B.L. (1992) Evidence for two phosphonate degradative pathways in Enterobacter aerogenes. J. Bacteriol. 174(8): 2501-2510. 
Mañas F., Peralta L., Raviolo J., Ovando H.G., Weyers A., Ugnia L., Gorla N. (2009) Genotoxicity of AMPA, the environmental metabolite of glyphosate, assessed by the Comet assay and cytogenetic tests. Ecotoxicol. Environ. Safety 72(3): 834-837.

Sarkar M., Hamilton C.J., Fairlamb A.H. (2003) Properties of phosphonoenolpyruvate mutase, the first enzyme in the aminoethylphosphonate biosynthetic pathway in Trypanosoma cruzi. J. Biol. Chem. 278(25): 22703-22708.

Skeff W., Neumann C., Schulz-Bull D.E. (2015) Glyphosate and AMPA in the estuaries of the Baltic Sea method optimization and field study. Marine Poll. Bull. 100(1): 577-585.

Ternan N.G., Quinn J.P. (1998) Phosphonate starvation-independent 2-aminoethylphosphonic acid biodegradation in a newly isolate strain Pseudomonas putida NG2. Syst. Appl. Microbiol. 21: 346-352.

Vinogradov E., Egbosimba E.E., Perry M.B, Lam J.S., Forsberg C.W. (2001) Structural analysis of the carbohydrate components of the outer membrane of the lipopolysaccharide-lacking callulolytic ruminal bacterium Fibrobacter succinogenes S85. Eur. J Biochem. 268: 3566-3576.

Wanner B.L. (1996) Phosphorus assimilation and control of the phosphate regulon. [in:] Escherichia coli and Salmonella: cellular and molecular biology. Ed. Neidhardt F.C., Curtis R.I., Gross C.A., Ingraham J.L., Lin E.C.C., Low, K.B. Jr., Megasanic B., Reznikoff W., Schaechter M., Umbarger H.E., Riley M. Amer. Soc. Microbiol. Washington: 1357-1381.

Weiland M., Daro A., David C. (1995) Biodegradation of thermally oxidized polyethylene. Polym. Degrad. Stabil. 48: 275-289.

Zboińska E., Maliszewska I., Lejczak B., Kafarski P. (1992) Degradation of organophosphonates by Penicillium citrinum. Lett. Appl. Microbiol. 15: 269-272. 